\title{
Myth-Making - Or Just Taking the Myth? The Dangers of Myth Becoming Fact in Lewis's Narnia Series
}

\author{
David Rudd
}

$\mathrm{T}$ Whis paper arises out of my own perplexity at some of C.S. Lewis's comments about the reception of his Narnia series. He repeatedly claimed that young readers were more 'receptive' to his intentions than adults, as the two following remarks attest. The first was specifically addressed to a 'young reader'; the second, a more general comment, was written just two days before he died:

I'm so thankful you realized the 'hidden story' in the Narnian books... It is odd, children nearly always do, grown ups hardly ever.

(Sibley 1989. p.89)

It's a funny thing ... that all the children who have written to me see at once who Aslan is, and grown ups never do!

(ibid.. p.91)

My experience with readers, including many cohorts of children's literature students and delegates to whom I've posed the question at conferences, has been the opposite: almost no children realise the 'hidden story': few adults avoid it. ${ }^{1}$. 1 have atso solicited children's views on what the stories are about. Hardly any notions of a 'hidden story' have been offered by the latter, or by the former in recalling their childhood reading. I have therefore come to the realisation that the children who understand Lewis's Chronicles do so in terms that are strictly Lewis's own: that is, precisely by not seeing the message. Adults, on the other hand, because they do see the message. fail, in Lewis's sense, to appreciate his stories properly.

I want to explore the sense behind this paradox, starting from Lewis's own ideas about what he thought he was doing in writing the Chronicles. I still end up critical of his enterprise but. unlike some other critiques (e.g. Holbrook 1973: Goldthwaite 1996: Pullman 1998), I hope to do justice to Lewis's avowed intent. Let me begin by outlining Lewis's thoughts. drawing, as much as possible. on his own writings.

Steal past watchful dragons...

It is ironic that some of the key statements about his intentions come from an essay entitled, 'Sometimes fairy stories may say best what 's to be said' (Lewis 1966), the fairy story usually being seen as more of a pagan form. where magic, chance and fate, rather than a divine presence, are the norm (e.g. Nodelman 1977; Purkiss 2000). But this, in fact, fits Lewis's purpose, which was to have the reader experience the potency of the Christian story at first hand. This was important to him because, as a youngster. Lewis himself confessed that he did not experience its power, specifically because of the dry way the Christian story was presented to him. He writes of 'a certain inhibition which had paraly'sed much of my own religion in childhood', involving 'obligation ... [a]nd reverence', being 'associated with lowered voices', like 'something medical' (Lewis 1966, p.37).

Paradoxically, all other myths held this power for him, and he celebrates their potency:

In the enjoyment of a great myth we come nearest
to experiencing as a concrete what can otherwise
be understood onlyas anabstraction ... It is only
while receiving the myth as a story that you
experience the principle concretely.
(Lewis 1971, p.42)

As he expresses it elsewhere. 'The more lucidly we think. the more we are cut off: the more deeply we enter into reality, the less we can think' (Lewis 1971, p.41). His model for such evocative writing. and a profound influence on his own fictional development, was the 'mythopoeic art' of George MacDonald. Such art. Lewis writes,

goes beyond the expression of things we have already felt. It arouses in us sensations we have never had before, never anticipated having, as though we had broken out of our normal mode of consciousness and 'possessed joys not promised to our birth'. It gets under our skin, hits us at a level deeper than our thought or even our passions. troubles oldest certainties till all questions are re-opened, and in general shocks us more fully awake than we are for most of our lives.

(Lewis 1946, pp.16-7)

Elsewhere, commenting on MacDonald's The Phantastes (1858), Lewis elaborates on how the book conveys a sense of expansiveness in the reader:

Everyone... who feels the story, will read its meaning after his own nature and development 
.... A genuine work of art must mean many things: the truer its art, the more things it will mean. (Lewis, quoted in Carpenter 1978, p.80)

It is on this basis that Lewis can claim as 'moonshine' notions that his work is allegorical, lampooning the idea that he 'began by asking ... how [he] could say something about Christianity' to children; then fixed on the fairy tale as an instrument ...then drew up a list of basic Christian truths and hammered out "aljegories" to embody them" (1966, p.36). Allegories, to his mind, arise from factual issues which are then dressed up in fictional garb - as in The Pilgrim's Progress (1678) - whereas he, on the other hand, starts with concrete. fictional images, into which he introduces a factual figure (Jesus Christ), and lets the implications work themselves out imaginatively:

Supposing that there really was a world like Narnia and supposing it had (like our world) gone wrong and supposing Christ wanted to go into that world and save it (as He did ours) what might have happened? The stories are my answers.

(Lewis. quoted in Hooper 1966, p.426)

The key difference between allegory and mythopoesis lies in the fact that Lewis claims to have been imaginatively inspired. rather than starting with an abstract idea (or dogma) for which he then found suitable fictional vehicles. With Narnia, according to Lewis,

Everything began with images; a faun carrying an umbrella, a queen on a sledge, a magnificent lion. At first there wasn't anything Christian about them; that element pushed itself in of its own accord. (1966. p.36)

Given this. we might not expect Lewis to be overly impressed with the critical industry that has grown up around his series. with scholars seeking to ground his work in specific Biblical episodes (e.g. Sammons, 1979). Such activity has an especially ironic quality given that Lewis also writes approvingly of the fairy tale's resistance to secondary' meanings, having. as he puts it. an 'inflexible hostility to afl analysis' (Lewis 1966, pp.36-7).

\section{...But never tickle a sleeping one}

Most of us can follow the logic of Lewis's case and, no doubt, reflect on particular mythical stories that have profoundly affected us; indeed. Lewis's own Chronicles of Narnia may well be on that list. However. Lewis's poetic account of the Chronicles' origins is not the whole story, any more than is the young reader's claim that the books are simply a delightful fantasy. Following the example of the sixteenth-century poet, Tasso. Lewis sees the imaginative writer as being driven by two concerns. The one I have just quoted is that of 'the poet'. who, 'as poet [is] concerned solely with pieasing'; but, writes Lewis, the poet is 'also a man and a citizen', who 'ought to, and would wish to, make his work edifying as well as pleasing' (1966, p.35). (For many of us, this distinction captures that perennial tension in children's books, between entertainment and instruction.) So having established the virtue of his fairy tale, emerging poetically from a few images - Christianity having "pushed itself in of its own accord", without any allegorical intent-Lewis then lays out 'the Man's motive'. This seems less innocent, even when recounted in Lew'is's own words:

\section{But supposing that by casting all these things [Christian concerns 'about God or ... the sufferings of Christ'] inio an imaginary world, stripping them of their stained-glass and Sunday school associations, one could make them for the first time appear in their real potency? [sic] Could one not thus steal past those watchful dragons? I thought one could. \\ (Lewis 1966, p.37)}

Though the writer's stealth is given a positive spin - that is, being seen as a necessary subterfuge to escape the stifling apparatus of the church's version of Christianity - it still involves sneaking past the conscious mindset of the individual. Lewis says as much earlier in the passage from which I quoted earlier: 'stories of this kind could steal past a certain inhibition which had paralysed much of my own religion in childhood ... [and which] can freeze feelings' (Lew'is 1966, p.37). 
Lewis is thus advocating a tried and tested technique in children's literature, familiar from, for instance, the work of Hannah More (1745-1833), who, upset that the chapbook was so successful, appropriated its format for her own morally uplifting Cheap Repository Tracts (17958). with great success. However, Lewis's defence might be that, unlike Hannah More, for him the poetry preceded the morality. Another example, more widely recognised, would be the move made by early Christians in appropriating the pagan festival of Saturnalia, turning it into their own 'Christmas'. Yet, even here, Lewis has a slightly different notion of what I have termed 'pagan'. His view is connected with his Platonism, which sees all myths as basically surface representations of a deeper, underlying reality: "the Pagan stories are God expressing Himsclf through the minds of poets, using such images as He found there, while Christianity is God expressing Himself through what we call "real things" (Lewis 1979, p.427).

God. then. is always and forever present, but, whereas in the pagan stories He uses man's imagination as a conduit, in Christianity there is no such need, as the historical events speak for themselves - except, of course, that they do nol. which is why. once again, Lewis decided to use the fairy talc. In sncak past the watchful dragons that had kenl him from cxperiencing the reality of Christianity.

I think 1 have circled round this issue long enough for the Ienor of l.ewis's reasoning to be grasped. But we are still left in a quandary: if it is God working through Lewis's imagination. inseminating it with the idea of a leonine saviout (just as the Holy' Spirit visited the Virgin Mary), then why the need for anything more explicit? Might there not he a danger, in fact, that the inspired poet's work will end up cmasculated by the worthy citizen (Tasso's other facei). allegorically charged and morally barbed?

In shor. I am suggesting that the Chronicles might be more successful in exemplifying Lewis's theoretical position than he at first realised: not only do they show a potent myth at work, but atso how that myth can become undone. its magic fading when the preacher starts to show. Then 'Nyth becomes fact' (to adapt a phrase of l.ewis"s) in at more prosaic manner.
So, to return to my opening paradox, it would seem that, as many children have attested, Lewis managed to create a powerful, moving, and numinous tale, which, like many of MacDonald's works, is infused with a sense of the spiritual. When children wrote to Lewis of how the books got under their skin, shocked and troubled them, Lewis could count himself successful in his myth-making.

But, just as the young Lewis found Christianity ruined for him by the watchful dragons that insisted on reverentially lowered voices, the older Lewis, the man and citizen, could not be content with the poet's uncertainties and multiple meanings ( the truer its art, the more things it will mean' - Lewis, quoted in Carpenter, 1978, p.80). In fact, even the title of the key essay I have been quoting 'Sometimes fairy stories may say best what's to be said' - is revealing, suggesting exactly the opposite of what it explicitly argues: namely, that 'what's to be said' (the message) precedes and drives the story, rather than growing imaginatively from it.

Rather than the ecumenical openness that he discerns in MacDonald (and which he himself was to achieve elsewhere, in the far less dogmatic Till We Have Faces (Lewis, 1956b)), we have a very specific form of Christianity thrust upon us, let alone his views on divers matters (e.g. education, underwear, vegetarianism). To put it in Lewis's own terms, while the pagan stories still have God's expression behind them, giving them a certain power, the Narnian stories lose precisely to the extent that their creator plays authorial God. He is then guilty of the very thing that initially he sought to avoid. Instead of stealing past the dragons, Lewis cannot help but draw attention to them. Well might he have heeded the Hogwarts motto: 'Never tickle a sleeping dragon' (Rowling, 1997).

\section{Myth becomes fact ... becomes myth-take?}

The more that Lewis the man obtrudes, the more that Lewis's myth becomes mythical in Roland Barthes' ideological sense; that is, it both 'makes us understand something and it imposes it on us' (Barthes 1973, p.126). Briefly, Barthes' model draws on Saussure's conception of the linguistic sign as comprising both signifier (form) and signified (concept), and the fact that both elements 
are ultimately arbitrary (in that different languages carve up the world differently). But those in power would have us believe that such 'cultural cuts' are, in fact, natural; that they cncode universal truths: for example, in Victorian England, the patriarchal notion that woman was a frail vessel, or in the UK in the 1980s, Margaret Thatcher's attempt not only to re-appropriate 'Victorian Values', but also to persuade the nation of their eternal verity.

In Barthes' model of myth, an assemblage of pre-existing linguistic/visual signs is taken and treated as a container (a signifier) by emptying out its current meaning (the signified) and replacing it with a secondary meaning, which is then read as 'natural'. The diagram below, adapted from Barthes' framework in 'Myth Today', suggests how Lewis sees his own second-order, mythical signification working on us.

Signifier Aslan dies in place of Edmund in fantasy world of Narnia, and subsequently returns to life.

Signified Aslan, an all-powerful god in a fictional world, atones for another's wrong and overcomes evil.

Sign $[+$ Signifier $]=$ Aslan is the god-like saviour of a human in a moving fantasy.

Signified Jesus Christ died to save humanity on Earth.

$2^{\text {nd }}$ Order Signification = Aslan's power to move us is really Christ's power working on the reader, and to which s/he should be receptive. This myth is therefore a reality: not only historically true but experientially verifiable todiay.

So, although Lewis maintains that he works from a purely imaginative base, contra allegory's factual origins, he feels successful to the extent that this factual basis is invoked; namely, the mythical potency of Christ whom we can welcome into our hearts. A letter to J.R.R. Tolkien says as much: 'The essence of a myth ...[is] that it should have no taint of allegory to the maker and yet should suggest incipient allegories to the reader' (quoted in Carpenter 1978, p. 30). Though not strictly allegorical, Lewis certainly intends the bottom line of the above diagram to he the 'bottom line'.

There are explicit passages in the books to this effect, which are certainly not essential to the story. For instance, here is Aslan referring to the children's home in England:

'But you shall meet me, dear one, 'said Askan.

'Are - are you there too. Sir?' said Edmund.

'I am,' said Aslan. 'But there I have another name. You must learn to know' me by that name. This was the very reason why you were brought to Narnia, that by knowing me here for a little, you may know me better there.'

(Lewis 1952, p.222)

It might seem strange that the Pevensie children do not pick up on such heavy hints, but this is exactly what Lewis claims he wants: for them to experience the magic and majesty of Aslan without the churchifying baggage. Yet, if this is the case, then such passages are actually harmful, detracting from Aslan's intrinsic powerespecially when the reader does finally make the connection:

Laura Miller's experience, related in an article where adult authors talked about childhood books that influenced them, is typical. She singles out The Lion, the Witch and the Wardrobe, and especially the power of the scene where Lucy first goes through the wardrobe into Narnia (though she didn't then know what a wardrobe was!). She writes about how she loved 'Lucy's blind fingers feeling wool and fur turn to brittle twigs':

I used to long so powerfully for that same passage. I could almost sense the transformation against my own palms. It seemed to me that the need (my need) for Narnia's existence was so great that the place had to be real. somehow, somewhere. There had to be something more than the world I was stuck in.

\section{Powerful indeed! But, she continues,}

Lewis' hooks are very, very English and wery Christian, in a particular way. The latter I didn't realize until I was a good deal older, and this discovery filled me with anger and bitterness. I had been betrayed, ricked into giving my heart to the very noxious, twisted religion I had tried so hard to clude.

(Miller, 2000) 
It is an experience I have rarely heard in relation to other children's fantasies: that sense of being cheated. It is a move from the root sense of 'apocrypha', the 'hidden things', to its more common meaning, signifying the spurious. It is worth looking more carefully at how this process is built into the very fabric of the Narnia books, by exploring Lewis's myths in terms of Primary and Secondary Worlds.

\section{Primary and secondary worlds}

George MacDonald made the point that, once a fantasy world has been established, its tenets must be heeded, else its magic will suffer. Tolkien developed this notion, using the terminology 'Primary World' to talk about our everyday reality, as opposed to the 'Secondary World'. an imaginative sub-creation that can be entered. but whose spell can easily be broken if disbelief arises: 'You are then out in the Primary World again, looking at the little abortive Secondary World from outside' (Tolkien 1964, p.36).

Lewis's work seems to be flawed in this regard. It is of note that Tolkien himself thought so, finding the mixing of different mythologies unacceptable, unlike the more carefully realised world of his own 'Middle Earth'. Tolkien specifically commented on The Lion, The Witch and the Wardrobe, 'It really won't do, you know? I mean to say: 'Nymphs and their Ways, The Love-Life of a Faun.' Doesn'the know what he's talking about?'(quoted in Hooper 1996, p.402). Tolkien is here referring to a volume that the faun, Tumnus, has on his bookshelf, presumably making the point that drawing attention to the love life of hirsute fauns might suggest that they are less than suitable company for a young girl to take tea with: stripped of stained-glass associations, a faun might prove more potent than Lewis realised! (the subtitle, The Love-Life of a Faun, is not in Lewis's novel, of course; it is Tolkien's extrapolation).

But a more blatant disturber of the fantasy is Father Christmas. who marks the commemoration of Christ's birth in the Primary World, only to appear incongruously in Lewis's Secondary one. He augurs Christmas, giving the children presents, although, curiously, he does not have one for Edmund, whereas even Aslan feels the need to ask 'But where is the fourth?' (Lewis 1950, p.119).
The main point, though, is that, if anything, it should be Aslan's birthday that is celebrated in Narnia, not Christ's. However, as the lion is never incarnated there (despite Narnia's fallen status), this presents problems, which will discuss later.

Unlike Tolkien, Lewis finds it easy to mix and match mythologies. In his Platonic view both Earth and Narnia are mere 'shadowlands': spectres of a deeper reality. Hence the Primary and Secondary Worlds are both epiphenomenal when compared to what we might term a 'Tertiary' realm. Thus Roman, Norse, Greek, Arabic, Celtic and English mythical beings can easily co-mingle as manifestations of an underlying reality. In this sense, man is indeed a myth-as is the Narnian to most Earthlings: a mere expression of something deeper. Lewis makes this point most clearly in The Last Battle, where the real Narnia is introduced. along with the essence of what Aslan stands for. As the lion explains it to Emeth, the Calormene:

'if any man swear by Tash and keep his oath for
the oath's sake, it is by me that he has truly sworn,
though he know it not, and it is I who reward him.
And if any man do a cruelty in my name, then,
though he says the name Aslan, it is Tash whom
he serves and by Tash his deed is accepted.'
(Lewis 1956a, p.166)

Let me re-emphasise, though, that this only becomes an issue if the books are seen to have a hidden story, rather than being moving stories per se. If the Chronicles are read simply as mythology, there is no problem. Yet, it must be said that Lewis is often quite explicit in pointing the reader in the 'right' direction-as the passage from The Voyage of the 'Dawn Treader' quoted earlier shows. You can almost hear Lewis hailing his intended reader: 'This was the very reason why you were brought to Narnia, dear reader, that by knowing me here for a little, you may know me better there' (Lewis 1952, p.222, with my emphasis). The more that Lewis, on his less than stealthy path, plays with such dragons, the more likely it is that his incipient allegorical meanings will become full-blown (Aslan tellingly speaks at one point of the "chinks or chasms between that world and this' [Lewis 1980. p.185]) It is as these incongruities are bared that the credibility of 
Narnia starts to collapse - which. for many readers. is a long while before the funal apocalypse of The Last Battle.

One of the main chinks is the conflation of the trinity into Aslan. Although he is said to be the son of the great Emperor-beyond-the-sea' (Lewis 1950, p.77), this latter figure does not feature at all. Instead, it is Aslan who performs the creation of Narnia, singing it into existence, just as it is Aslan who supervises its Armageddon, sorting the sheep from the goats. ${ }^{2}$ By making Aslan more powerful in this way, though, Lewis'screation effectively loses much of the humanity of Jesus in the New Testament. In the Bible, lesus is incarnated into society and lives among humankind for thirty-three years; Aslan, however. is from the outset a far more transcendent being. putting in only occasional appearances. often in the role of a deus ex machina.

This makes his Passion, in particular, lose much of its power. For instance. in his sacrifice on the Stone Table, Aslan is saving the very world that he was responsible for creating. so there is no hint of him being at risk, of crying out, 'My God, my God, why hast thou forsaken me?'; for Aslan simply is God. His godhead also undermines his pact with the White Queen. where Aslan substitutes himself for Edmund according to the Deep Magic-which, it should be noted, 'is engraved on the sceptre of the Emperor-Over-Sea... Magic which the Emperor put into Narnia at the very beginning' (Lewis 1950, p.130). Yet Aslan later emerges, resurrected, as a result of the Deeper Magic. of which the Queen seems unfairly ignorant:

'if she could have looked a little further back ... she would have read there a different incantation. She would have known that when a willing victim who had committed no treachery was killed in a traitor's stead, the Table would crack and Death itself would start working backwards.

(Lewis 1950, p.150)

This has the ring of Rule 42, quoted to Alice in her Wonderland adventures: 'All persons more than a mile high to leave the court' (Carroll 1965, p.156). In other words, it sounds suspiciously opportunistic -especially as Aslan says nothing to the girls about its existence beforehand:
'Oh. Aslan!' whispered Susan in the lion's ear. 'can't we-Imean, you won't, willyou? Can't we do something about the Deep Magic? Isn't there something you can work against it?'

'Work against the Emperor's Magic? 'said Aslan, turning to her with something like a frown on his face. And nobody ever made that suggestion to him again.

(Lewis 1950, p.131)

Clearly, when he previously talked about the 'Magic which the Emperor put into Narnia at the very beginning' (Lewis, 1950, p.130), he did not really mean the beginning. It is not the oldest rule in the book after all! The fact that Aslan must have been aware of this devalues the impact of his sacrifice, though it does account for him emerging from the ordeal much the same as before: not transfigured in any way. There is also a lack of redemptive significance in Aslan making this sacrifice, in that it is never referred to again, and certainly no Narnians feel the need to hold services in religious buildings, or wear images round their necks of a lion recumbent on a stone-table!

Let it be stressed again. if there were not these explicit links with the Christian mythology of the Primary World, there would be no problem: but the more we excavate Lewis's hidden story, the "farther up and farther in' (to use his own phrase) we become embroiled. So. in that Lewis explicitly has the Narnians refer to the children as Sons of Adam and Daughters of Eve. we are forced to see them as part of a differen mythology, one where Jesus has already lived (hence the celebration of Christmas, not Saturnalia) and died to atone for humankind 's sins; and, of course, in this mythology, humans were created in God's 'own image' (Genesis. 1:27). In which case, why does Aslan, a lion at that, atone yet again for a human, rather than for the Narnians? Why, indeed, is it only one human - Edmund - not humanity, for whom Aslan sacrifices himself? Why not for Tumnus, or the other animals that have been turned to stone in the Witch's courtyard - especialty his chosen. talking ones?

Once these chinks start showing. others inevitably appear. So, it is also worth asking. in what sense is Edmund a traitor? How does he equate with Judas, or the other 
sinners of the Bible for whom Jesus atoned? There is selfishness and sibling rivalry, certainly, but Edmund's treachery is accounted for plot-wise by the White Queen's enchanted Turkish Delight, which obsesses him (and, of course, by being sent to 'that horrid school which was where he had begun to go wrong' [Lewis, 1950, p. 165]). He does not seem to have the free choice that, say, Digory faces in the prequel, The Magician's Nephew, when tempted by Jadis's offer of a healing apple for his sick mother (Lewis, 1955).

In fact, Edmund's sin seems to pale into insignificance compared with the subsequent denial of his sister, Susan. by all three of her siblings. Queen Susan the Gentle, as she came to be known in Narnia, is then dismissed: " $M y$ sister Susan." answered Peter shortly and gravely, "is no longer a friend of Narnia" (Lewis 1956a, p.138). She has been forbidden entry to the promised land because, as Jill explains, she's 'a jolly sight too keen on being grown-up' - although both Lucy and Edmund had earlier been told by Aslan that they were getting 'too old' for Narnia, and advised to 'come close to your own world now' (Lewis 1952. p.222). It is difficult not to think that Saints Paul and Augustine-let alone Edmund-were fortunate not to have Lewis judge their youthful behaviour! Of course, a defender of Lewis might argue that this rejection of family members finds a precedent in Jesus's own words: 'For I am come to set a man at variance against his father, and the daughter against her mother" (Matthew 10:35). But justifying his texts by pointing to particular Biblical passages rapidly causes the work to lose its imaginative origins and begin to unravel into allegory. Not only that, but it is clear that it is Lewis's own rather bullish, muscular version of Christianity that is being allegorised (Holbrook 1977: Goldthwaite 1996).

One final point about Lewis's Day of Judgement is the way that it presents problems at the point where the Primary and Secondary Worlds interface. I have already drawn attention to the fact that it is Aslan who presides over events-not the Emperor beyond the sea-consigning some of the privileged talking animals to muteness. despite their earlier freedom to eat their dumb namesakes. But why are the humans here at all? Presumably the human world carries on, to have its own Judgement Day at some future time - over which the Emperor across the sea might preside. So why won't these Sons of Adam and Daughters of Eve be involved in that? Will Susan be given another chance at this Earth-based hearing, in the manner of a prodigal son (though she is hardly that)? Lewis might argue that, because both these worlds are insubstantial shadowlands, it does not really matter which Judgement Day one takes part in. However, this is not what Aslan says in The Voyage of the 'Dawn Treader'. When Lucy asks him (then disguised as a lamb), "Is this the way to Aslan's country?", he replies, "Not for you .... For you the door into Aslan's country is from your own world" (Lewis 1952, p.221).

It should be clear, then, that Lewis has made exceptional problems for himself by linking the mythology of his Secondary World to that of the Primary - problems that Tolkien avoids, as do most other fantasy writers. They write about myth with a small ' $\mathrm{m}$ ', still managing to create coherent worlds where good and evil are played out. Their mythologies are certainly potent and have implications both for ourselves and for our society, but they don't try to go any further (in). Lewis, however, not only seeks to link the Secondary and Primary Worlds but, as noted above, depicts both as inconsequential when compared with a 'Tertiary World', which we view most clearly at the end of The Last Battle. This is not simply a spiritual world; it is Christian in a most specific way. Lewis may well have stripped away the stained glass but, in the process, he has removed much of the leading from the roof, too! His pure. unsullied Christianity (guaranteed Sunday School free) - the platonic kernel of faith - thus shows its ideological roots in a rather curmudgeonly old don (see A.N. Wilson's biography). ${ }^{3}$ However, it is not necessary to invoke the man, for the characteristics are there in the text, in the overbearing narration.

The nature of Lewis's Christianity is tellingly related in his notions of Deep and Deeper magic. As mentioned earlier, the Deep Magic is in fact the Old Testament law: lex talionis, an eye for an eye. hence Aslan for Edmund. The Deeper Magic is supposedly the New Testament covenant: of an innocent dying to atone for our sins. This, we are told, goes back to before the dawn of time. However, in the Bible the new covenant is a more recent 
revelation. auguring a less vengeful, more compassionate era of Christianity. Aslan, unfortunately, retains a great deal of the Old Testament autocrat. and generally seems to work with this more aggressive. deep magic, rather than that of the new covenant. As said earlier, his transfiguration, if it occurs at all, seems to alter him very little.

He certainly believes in fighting the good fight, carrying the sword into battle rather than turning the other cheek, and encourages the same in his followers: as Iill Pole says in The Last Battle. "I'd rather be killed fighting for Narnia than grow old and stupid at home" (Lewis 1956a, p.99) (a line. incidentally. which Margery Hourihan (1997, p.23) traces back to mythical heroes in the Epic of Gilgamesh). Aslan also takes quite literally the eye for an eye covenant, as can be seen when when he jabbed at Aravis with ... [his] right paw ... all the terrible claws extended ... tearing her shoulders` (Lewis 1965a, p. 123), and we are told that this was for Aravis' own good:

"The scratches on your back, tear for tear, throb for throb, blood for blood, were equal to the stripes laid on the back of your stepmother's slave because of the drugged sleep you cast upon her. You needed to know what it felt like." (Lewis 1965a, p.169)

Aslan even deems it his business to come 'over to ${ }^{\circ}$ Earth to sort out some child bullies at a progressive school:

$$
\begin{aligned}
& \text { they saw the wall fallen down, and a lion as large } \\
& \text { as a young elephant lying in the gap, and three } \\
& \text { figures in glittering clothes with weapons in their } \\
& \text { hands rushing down upon them. For, with the } \\
& \text { strength of Aslan in them, Jill plied her crop on } \\
& \text { the girls and Caspian and Eustace plied the flat } \\
& \text { of their swords on the bovs so well that in tw'o } \\
& \text { minutes all the bullies were running like mad, } \\
& \text { crying out, 'Murder! Fascists! Lions! It isn't } \\
& \text { fair.' } \\
& \text { (Lewis 1965b, p.205) }
\end{aligned}
$$

Clearly this is not how Lewis tells us he first envisaged Narnia: 'supposing Christ wanted to go into that world and save it' (quoted in Hooper 1996, p.426). There is a complete confusion of realms here. The school episode would be equivalent to Jesus nipping off from Galilee with a few armed disciples in order to sort out Maugrim and his henchmen when they set about ransacking the home of Tumnus.

\section{CONCLUSION}

In 'Myth Today'. Roland Barthes speculated about adding a third level, 'a third semiological chain' (1973. p.147). to his diagram (adapted above), through which the mythologist might undo myth. However, it seems to me that Lewis. by displaying his irascible Christianity and other prejudices so overtly, effectively does this himself. Aslan, in Lewis's imaginary world, might be the perfect vehicle to steal past watchful dragons, helping the reader appreciate what a potent container the Narnian myth is. but to work in this way it must be left open to the reader to provide the emotional depth: the my'th musl resonate with the individual psyche. As Lewis says of MacDonald. his strength lay in questioning certainties, in opening up meanings, not harnessing them to particular doctrinal truths. Lewis may have removed the stained glass, but, like some persistent double-glazing salesman, he seems to want to replace it with his own uPVC variety. The result is a myth that is fine so long as it remains mysterious and apocry phal in the root sense (i.e. hidden): but, as soon as the myth. or hidden story, is spotted, it rapid ty becomes more conventionally apocryphal (i.e. spurious). Myth then becomes fact only to become. for many mature readers. a dreadful myth-take. The Narnian world then starts to deconstruct before ever Aslan comes along to strike the set. 


\section{NOTES}

1. Brian Sibley (1989, p.92) says that Pauline Baynes did not see the associations at all during the course of illustrating all seven volumes! However, other acquaintances of Baynes have told me that this was not the case

2. The Witch does speak of 'the Magic which the Emperor put into Narnia at the very beginning' (Lewis 1950, p.130), but Aslan alone is shown performing Narnia's creation.

3. The man is pursued, however, in David Holbrook (1991), and more recently in John Goldthwaite, the latter calling Lewis 'a contortionist at exegesis' (1996, p.237), emphasising how personal events distorted his Christianity.

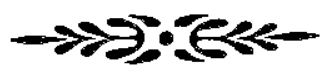

\section{REFERENCES}

Barthes, Roland (1973) 'Myth today'. in Mythologies. London, HarperCollins, pp.117-74.

Carpenter, Humphrey (1978) The Inklings: C.S. Lewis, J.R.R. Tolkien, Charles Williams, and their Friends. London, Allen \& Unwin.

Carroll, Lewis (1965) The Annotated Alice. Harmondsworth, Penguin.

Goldthwaite, John (1996) The Natural History of Make-Believe: A Guide to the Principal Works of Britain, Europe, and America. Oxford, Oxford University Press.

Holbrook, David (1973) 'The problem of C.S. Lewis', Children 's Literature in Education 19.3-25.

Holbrook, David (1991) The Skeleton in the Wardrobe: C.S. Lewis's Fatnasies: a Phenomenological Study. London, Associated University Presses.
Hooper, Walter (1966) C.S. Lewis: A Companion and Guide. London, HarperCollins.

Hourihan, Margery (1997) Deconstructing the Hero: Literary Theory and Children's Literature. London, Routledge.

Lewis, C.S. (1946) 'Preface' to George MacDonald: An Anthology. London, Geoffrey Bles, pp. 10-22

Lewis, C.S. (1950) The Lion, the Witch and the Wardrobe. London, Geoffrey Bles.

Lewis, C.S. (1952) The Voyage of the "Dawn Treader". London, Geoffrey Bles.

Lewis, C.S. (1955) The Magician's Nephew. London, Bodley Head.

Lewis, C.S. (1956a) The Last Battle. London, Bodley Head.

Lewis, C.S. (1956b) Till We Have Faces: A Myth Retold. London, Geoffrey Bles.

Lewis, C.S. (1965a) The Horse and his Boy. Harmondsworth, Penguin

Lewis, C.S. (1965b) The Silver Chair. Harmindsworth, Penguin.

Lewis, C.S. (1966) 'Sometimes fairy stories may say best what's to be said', in W.

Hooper (ed.) Of Other Worlds: Essays and Stories. London, Geoffrey Bles. pp.35-8.

Lewis, C.S. (1971) 'Myth became fact', in W Hooper (ed.) Undeceptions: Essays on Theology and Ethics. London, Geoffrey Bles, pp.39-43 [orig. 1941]

Lewis, C.S. (1979) They Stand Together: The Letters of C.S. Lewis to Arthur Greeves (1914-1953), ed. by W. Hooper. London, Collins.

Lewis, C.S. (1980) Prince Caspian: The Return to Narnia. London, Collins. 
Miller, Laura (2000) 'Personal Best' Salon Internet Magazinte, December 2000. [http:// www.salon.com/weekly/lewis $960930 . \mathrm{html}]$

Nodelman. Perry (1977) "What makes a fairy tale good: the yucer kindness of 'The Golden Bird' CLE. 26: 101-8: also in Geoff Fox (ed.) Celebrating Children's Literature in Education: A Selection. London. Hodder \& Stoughton, 1995, pp. 21-8

Pullman, Philip (1998) 'The dark side of Narnia', Guardian, 1 October.

Purkiss, Diane (2000) A History of Fairies and Fairy stories. London, Allen Lane.

Rowling, J.K. (1997) Harry Potter and the Philosopher's Stone. London. Bloomsbury.

Sammons, Martha C. (1979) A Guide through Narnia. London. Hodder \& Stoughton.

Sibley. Brian (1989) The Land of Narnia: Brian Sibley Explores the World of C. S. Lewis. London. Collins.

Tolkien, J.R.R. (1964) 'On fairy-stories', Tree and Leaf. London, Allen \& Unwin, pp. 11 70

Wilson. A.N. (1990) C.S. Lewis: A Biography. London, Collins.

\section{BIOGRAPHICAL NOTE}

David Rudd lectures in children's literature, education. and research methods at Bolton Institute, UK. His latest book. Enid Blyton and the Mystery of Children's Literature, was published by Macmillan in 2000 . Recent articles include studies of Biil Naughton. J.K. Rowling, Melvin Burgess, Catherine Storr, and E. Nesbit.

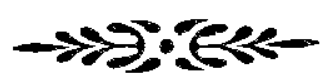

